\title{
Angling sport fishing in Lobo-Broa reservoir (Itirapina, SP, Brazil)
}

\author{
Pereira, JMA. ${ }^{\mathrm{a} *}$, Petrere-Jr, M. ${ }^{\mathrm{b} *}$ and Ribeiro-Filho, $R A .^{\mathrm{a} *}$ \\ ${ }^{a}$ Centro de Recursos Hídricos e Ecologia Aplicada, Escola de Engenharia de São Carlos, \\ Universidade de São Paulo - USP, \\ Av. Trabalhador Sancarlense, 400, CP 292, CEP 13560-970, São Carlos, SP, Brazil

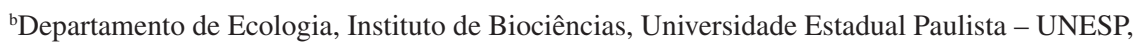 \\ CP 199, CEP 13506-900, Rio Claro, SP, Brazil \\ *e-mail: mpetrere@rc.unesp.br, juliaapereira@gmail.com, rarfilho@yahoo.com.br, \\ Received August 31, 2006 - Accepted November 30, 2006 - Distributed November 30, 2008
}

(With 9 figures)

\begin{abstract}
The objective of this paper was to study angling from September, 2002 to September, 2004 in the Lobo-Broa Reservoir, Itirapina, SP $\left(22^{\circ} 15^{\prime} \mathrm{S}\right.$ and $\left.47^{\circ} 49^{\prime} \mathrm{W}\right)$. Interviews (total 1,027) with sport fishers were accomplished in the three main fishing sites (Horto, Píer and Praia). This fishing was practiced with a simple fishing rod and reel, mainly in Horto, where the catches and fishing effort were higher. The catches were mainly composed of Cichlidae (Geophagus brasiliensis, Oreochromis niloticus, Tilapia rendalli and Cichla monoculus). We tried to determine which factors (fishing sites, type of baits and season) and the covariate fishing effort, expressed in number of fishing rods multiplied by fishing time, would affect catches, using a 3 way-ANCOVA. The final model showed that only fishing sites and effort determined the captures of sporting fishing in the reservoir. Some measures for managing fishing practices are discussed.
\end{abstract}

Keywords: sport fishing, cpue, ANCOVA, reservoir fishing management.

\section{As pescarias esportivas no reservatório Lobo-Broa (Itirapina, SP, Brasil)}

\section{Resumo}

O objetivo deste trabalho foi estudar as pescarias esportivas, entre setembro de 2002 e setembro de 2004 na Represa do Lobo-Broa, Itirapina, SP $\left(22^{\circ} 15^{\prime} \mathrm{S}\right.$ e $\left.47^{\circ} 49^{\prime} \mathrm{W}\right)$. Foram realizadas 1.027 entrevistas junto aos pescadores esportivos nos três principais locais (Horto, Píer e Praia). Estas pescarias foram praticadas com vara de pescar simples e com molinete, principalmente no Horto, onde as capturas e esforço pesqueiro foram maiores. A captura foi composta principalmente de Ciclídeos (Geophagus brasiliensis, Oreochromis niloticus, Tilapia rendalli e Cichla monoculus). Buscou-se detectar que fatores (locais de pescarias, tipos de isca e sazonalidade) e se a covariável esforço de pesca, expresso em termos de número de varas de pesca multiplicado pelo tempo de pesca, afetavam as capturas, usando uma ANCOVA trifatorial. O modelo final mostrou que apenas os locais de pesca e o esforço de pesca determinaram as capturas das pescarias esportivas na represa. Algumas medidas de manejo para as pescarias foram discutidas.

Palavras-chave: pescarias esportivas, cpue, ANCOVA, manejo de recursos pesqueiros.

\section{Introduction}

Fishing management is not related just to the fish stock, but should also address the human community in the social, economical and cultural aspects (King, 1995; Lucena, 2000). In the case of sports fishers, there is the need to consider the generated impact on the ecosystem (Kerkvliet and Nowell, 2000).

There is a world tendency in recognizing the economical and social importance of the worldwide increase in the sport, and specially in Australia, since MurrayJones and Steffe (2000) estimated that sporting fishing is practiced by about 4.5 million people. In Germany, the carp Cyprinus carpio stocks have been maintained stable mainly due to sports fishers, whose techniques are selective and related to bait size (Arlinghaus and Mehner, 2003). It is also one of the main leisure activities in Finland (Sipponen and Muotka, 1996), and the importance of the activity increased with the number of fishers, catches and profit that the activity has been generating (Sipponen, 2001). In the United States, in the beginning of the 90's, there were about 60 million sport fishers (Kendall, 1991). A great number of them are directed to catfishes in 282 of the 349 reservoirs examined 
by Miranda (1999). O'Connel (2003) points out the importance of sport fishing data on the Canadian Atlantic coast to estimate the salmon stock in the area.

Arlinghaus et al. (2003) consider fishing anagement and conservation strategies of industrialized countries focused almost exclusively on sport fishing, while developing countries still prioritize professional small-scale fishing for food safety. However, even in those countries, the emphasis on sport fishing and conservation is increasing as a consequence of globalization. The evolution of sport fishing in Europe is still small when compared to the United States, where there are more studies on the theme, and consequently, a more efficient management of its fishing resources.

Sport fishing, when badly planned may cause negative impacts to local society and to its surrounding habitat (Beni, 1998). So the activity, previously considered inoffensive, is now seen as potentially harmful: the presence of fishers can cause erosion to the river banks and reservoir margins, water pollution, inappropriate rubbish disposal, etc. Bell (1997) considered the wetlands suitable places for high catches and profits, associated to their high productivity.

In Brazil, studies on sport fishing are scarce. Catella (2005) verified a decline in the activity in the south Pantanal (59 thousand sport fishers registered in 1999, 43 thousand in 2000, 35 thousand in 2001 and 30 thousand in 2002) and this reduction has been causing economic difficulties for the fishing tourist industry in the area. In the National Park of Ilha Grande (state of Paraná), by means of personal interviews with sport fishers, the main factors which lead them to take up this leisure-time activity were identified: closer contact with nature, stress relief and wish to visit new places (Zacarkim et al., 2005). Agostinho and Gomes (2005) say that about 10 tournaments of sport fishing were realized in the reservoir of Itaipu and some tournaments involved more than 800 people; in spite of the capture per unit of effort being low in these tournaments, the total catches of most people involved in the activity became highly relevant for the landing statistics of the reservoir.

This paper describes the angling sport fishing in Lobo-Broa reservoir and determines the factors, together with the fishing effort, that determines the catches.

\subsection{Study area}

The Lobo-Broa reservoir (Figure $1-22^{\circ} 15^{\prime} \mathrm{S}$ and $47^{\circ} 49^{\prime} \mathrm{W}$ ), located between the municipal districts of Itirapina and Brotas, SP, was built in 1936 when damming the Lobo stream, Itaqueri and Geraldo rivers and other smaller streams (Argenton, 2004) with the initial objective of generating hydroelectric energy (Tundisi, 1986). Since then, its basin has been affected by unavoidable impacts, such as the discharge of untreated residential sewage, deforestation, sand mining, tourism and intense sport fishing (Tundisi et al., 2003; Jørgensen and Vollenweider, 2000). The climate of the area is of the type Cwa, according to Köppen; in other words, sub- tropical mesothermic, with a wet summer and dry winter, under the influence of cold fronts arriving from the south, mainly in the winter and autumn. The average annual pluviosity is of $1,300 \mathrm{~mm}$, and the dry season extends from April to September (Tundisi, 1986). Table 1 shows its main characteristics.

The hydrographic basin of the Lobo-Broa reservoir has been studied thoroughly over time, for its physical characterization (Nishiyama, 1991; Lorandi et al., 1983; Freire et al., 1980), riparian vegetation (Giampietro et al., 2004; Souza, 1977) limnology and primary production (Argenton, 2004; Milk and Espíndola, 2002; Abe et al., 2000; Angelini, 1995; Tundisi and Matsumura-Tundisi, 1995; Calijuri and Tundisi, 1990; Whitaker, 1987, Calijuri, 1985; Tundisi, 1977; Moraes, 1978; Rocha, 1978) and sediments (Dornfeld et al., 2002; Trinity, 1980; Strixino, 1973). In the 70's, some fish studies were accomplished, mainly on the biology of the main species, such as the growth of Geophagus brasiliensis (Barbieri, 1975; 1974) and of Gymnotus carapo (Barbieri and Barbieri, 1984); growth and reproduction of Leporinus friderici (Barbieri and Santos, 1988); reproduction of Leporinus octofasciatus (Barbieri and Barbieri, 1991), reproduction of G. carapo (Barbieri and Barbieri, 1984); reproduction of Astyanax bimaculatus and of A. fasciatus (Barbieri and Barbieri, 1988); reproduction and nutrition of L. friderici (Barbieri and Garavelo, 1981), reproduction of Cichla ocellaris (Souza et al., 2005) and the feeding of C. ocellaris (Velludo et al., 2005).

Surveys of the fish fauna were carried out by Albino (1987), who listed 15 fish species, belonging to 12 genera, 8 families and 5 orders and by Marinelli (2002), who listed 22 species distributed in 7 orders and 12 families. Fragoso et al. (2005) caught 23 species, 12 families and 7 orders. Pereira (2005), in experimental fishing carried out between 2002 and 2004, caught 7479 individuals distributed in five orders and 11 families and registered the presence of exotic species. The differences among these

Table 1. Characteristics of the Lobo-Broa reservoir.

\begin{tabular}{lc}
\hline Altitude & $770 \mathrm{~m}$ \\
Lake area & $6.8 \mathrm{~km}^{2}$ \\
Basin area & $227.7 \mathrm{~km}^{2}$ \\
Volume & $22,106 \mathrm{~m}^{3}$ \\
Maximum depth & $12 \mathrm{~m}$ \\
Medium depth & $3 \mathrm{~m}$ \\
Length & $8 \mathrm{~km}$ \\
Annual water level fluctuation & $2 \mathrm{~m}$ \\
Average water retention time & 20 days \\
Trophic state & Oligo/mesotrofic \\
Köppen climate classification & Cwa \\
Average annual pluviosity & $1,300 \mathrm{~mm}$ \\
Current uses & Water abstraction, \\
& leisure, sportfishing \\
\hline
\end{tabular}

Source: Modified from Straškraba and Tundisi (2000). 


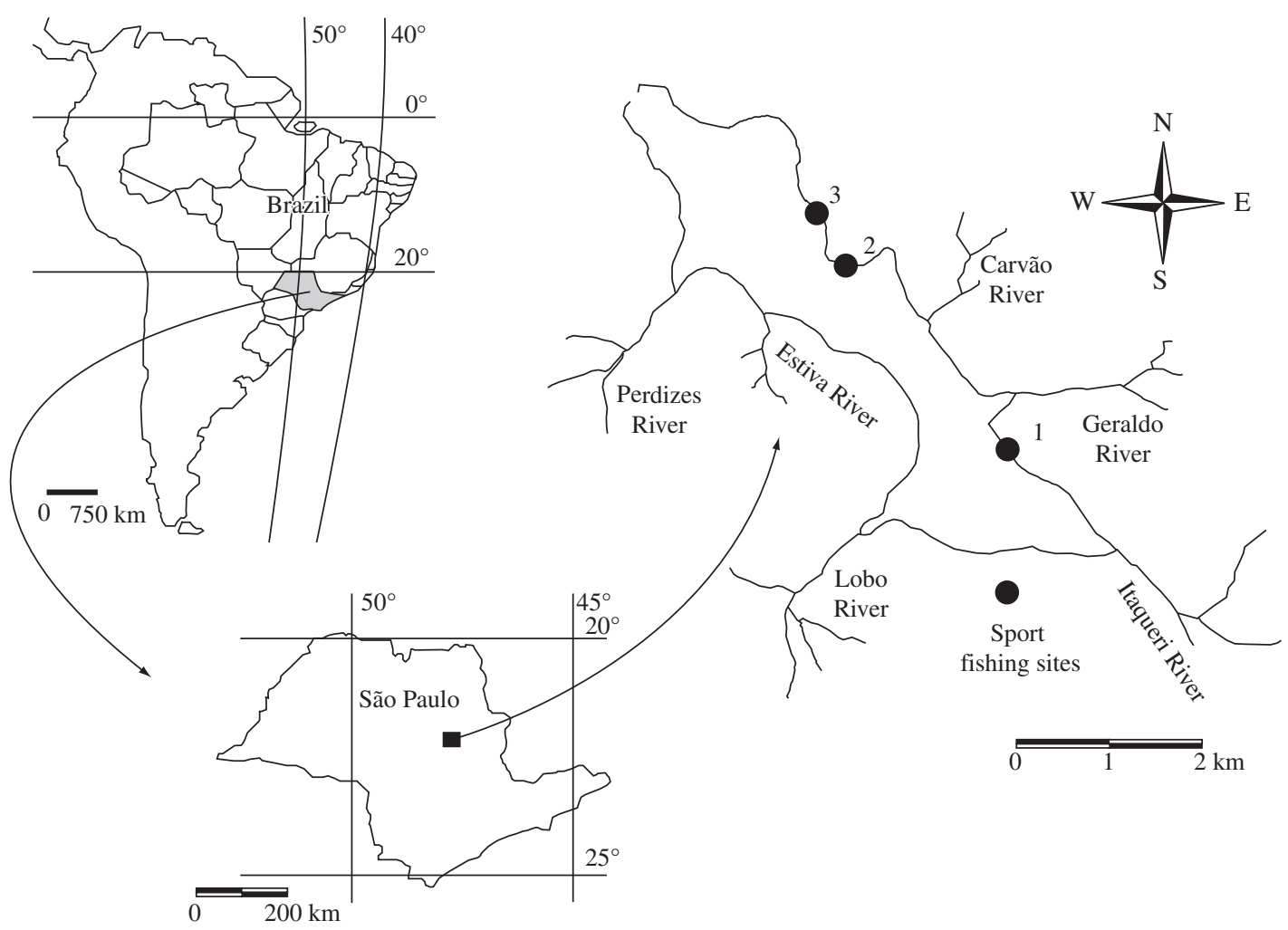

Figure 1. Main fishing sites where fishers were interviewed ( 1 = Horto, 2 = Pier, 3 = Praia) (Source: TUNDISI et al., 2004 , modified).

figures may be attributed to the different methods and fishing arts used in the study above (Table 2).

\section{Material and Methods}

From September to November of 2002, February to December of 2003 and January to September of 2004, 254 visits were carried out to the three main sites of sport fishing: Horto, Pier and Praia (Figure 1). We registered 1,027 fishers, some interviewed more than once during the field research. The visits to the fishing sites were accomplished in the morning (between 8:00 and 11:00 AM), as well in the afternoon (between 1:00 and 4:00 PM).

For each fisher we noted the date, fishing site, effective fishing time, fishing gear, baits used and species caught. Due to the high number of fishers, mainly in the hottest months, catch sampling at different fishing sites was alternated in each period. Fish were also weighed (individual total weight) and measured (TL, cm). In the other places, only the number of fishers present was counted. Data were further grouped in the dry and rainy seasons (dry: April-September; rainy: October-March).

The main gear employed was the simple rod with or without a reel. Sport fishing in the Lobo-Broa reservoir is practiced at three main places: 1) Horto: with access by means of fee paying; fishing by standing up or seated on palaffite benches. Some fishers use boats; 2) Praia: accessed via the Santo Antônio condominium; and 3) Pier: a structure built close to the Praia, also accessed via the Santo Antônio condominium.

\subsection{Catch and effort analysis}

Fishing effort was evaluated in two ways. In the fishing sites where fishers were just tallied, the effort was estimated only by number of fishers. At the other sites, where we had detailed data on catch and effort, the number of fishing poles (simple fishing rods) used by each fisher was multiplied by the effective fishing time (in hours). So for each fishing site, for the dry and rainy stations, both fishing efforts were calculated:

$\mathrm{f}_{\text {fishers }}=\sum \mathrm{n}_{\text {fishers }}$

where $\sum \mathrm{n}_{\text {fishers }}$ is the total number of fishers.

$\mathrm{f}_{\text {fishing }}=\sum\left(\mathrm{n}_{\text {poles }} \times \mathrm{t}\right)$

where $\mathrm{n}_{\text {poles }}$ is the number of simple fishing rods employed by each fisher and $t$ is the fishing time for each rod. 
Table 2. Taxa numeric comparison among the fish caught by Albino (1987), Marinelli (2002), Pereira (2005) e Fragoso et al (2005).

\begin{tabular}{|c|c|c|c|c|}
\hline & $\begin{array}{r}\text { Albino } \\
\text { (1987) } \\
\end{array}$ & $\begin{array}{c}\text { Marinelli } \\
(\mathbf{2 0 0 2}) \\
\end{array}$ & $\begin{array}{l}\text { Fragoso et al. } \\
(2005)\end{array}$ & $\begin{array}{c}\text { Pereira } \\
(\mathbf{2 0 0 5})\end{array}$ \\
\hline Order & 5 & 7 & 7 & 5 \\
\hline Family & 8 & 12 & 12 & 11 \\
\hline Species & 15 & 24 & 23 & 17 \\
\hline
\end{tabular}

The cpue was compared between the fishing sites and in the year (in the dry and rainy seasons) computed through:

cpue $_{\text {site }}=\frac{\sum \mathrm{cw}_{\text {site }}}{\mathrm{f}_{\text {fishing }}}$

where $\sum \mathrm{cw}_{\text {site }}$ is the capture of fishes in weight $(\mathrm{g})$ for each fishing site, and:

cpue $_{\text {season }}=\frac{\sum \mathrm{cw}_{\text {season }}}{\mathrm{f}_{\text {fishing }}}$

where is the capture of fishes in weight ( $\mathrm{g}$ ) for each fishing season.

\subsection{Statistical analysis}

Initially we produced a scatterplot between catch $\mathrm{x}$ effort in order to examine a possible linear relationship.

We tried to set up an ANCOVA on the catch (response variable) and effort data looking for possible factors which would affect the catches (Huitema, 1980). In order to balance the model and decreasing environmental noise (Petrere, 1978), data were grouped by seasons, fishing sites and type of baits (factors) (MurrayJones and Steffe, 2000; Wudneh, 1988; Pet et al., 1995; Okada et al., 1996; Paiva et al., 1994; Ribeiro and Petrere, 1990). Tests of normality $\left(g_{1}\right.$ - coefficient of asymmetry and $\mathrm{g}_{2}$ - coefficient of kurtosis) and residual analyses were carried out in order to validate the model. The model components were:

\section{a) Factors:}

S: season (1 = rainy; $2=$ dry); FS: fishing site ( 1 = Horto; 2 = Píer; 3 = Praia); BU: bait use ( 1 = just bait; 2 = bait + ceva; 3 = just ceva); $\mathrm{S} * \mathrm{FS}, \mathrm{S} * \mathrm{BU}, \mathrm{FS} * \mathrm{BU}$ : first order interactions; $\mathrm{S} * \mathrm{FS} * \mathrm{BU}$ : second order interaction.

b) Covariates:

ln f: natural logarithm of the fishing effort, expressed as the number of fishing rods multiplied by their fishing time.

The initial model was described by:

$\ln c w=\mu+S+F S+B U+\ln f+$ interactions $+\varepsilon$

where $\mu$ was overall mean and $\varepsilon$ random variable.

Furthermore, a multiple comparison test a posteriori following Fisher LSD $\mathrm{t}$ distribution was employed in order to detect significant differences between pairs of adjusted means (Huitema, 1980).

\section{Results}

\subsection{Fishing effort}

Figure 2 shows that the largest number of fishers/day (24.1) occurred in the rainy season of 2002-2003, and the second largest (14.0) was in the dry season of 2002. The distribution of number of sporting fishers per visiting day, by fishing site and season showed that the main fisher concentration occurred in the first rainy season (2002-2003), mainly in Horto. In the first dry season, the number of fishers/day was quite high, although there is not a preferred fishing site, when comparing with the following dry seasons, when fishers equally exploit the three fishing sites.

Fishing effort per season (Figure 3) shows that the largest fishing effort occurred in Horto in all seasons. The largest number of interviews was accomplished in the rainy season of 2002-2003 in Horto and in Píer, when there was also a larger number of fishers exploiting these sites (Horto: 58 interviews and effort 1155.76; Píer: 64 interviews and effort 887.99). Moreover, the largest relationship of fishing effort/ interview - was greater in Horto, in the dry season of 2003 (31.0) (Table 3).

The largest densities (fishers $/ \mathrm{km}^{2}$ ) were registered in the rainy season. The largest catch/fisher was registered in the 2002/2003 rainy season. In the dry season of 2004, the smallest fish production was registered, despite the number of fisher/ density being the second value of our study (Table 4).

\subsection{Use of baits}

The baits used by the sport fishers were earthworm, dough (prepared with flour and water), orange bug, live bait (characins or other small fish captured in the reservoir) and artificial bait. Fishers using only one bait type were $45.7 \%$, two types, $35.9 \%$ and three or more types, $6.7 \%$.

Some fishers use an oakum sac (ceva) full of ration with ground corn (quirera) and corn in grain which attracts fish for easing catches. The exclusive use of cevas $(11.7 \%)$ or associated to the bait $(64.1 \%)$ was also mentioned. In the first case, they practice lambada fishing which is done with two or more treble hooks (a set of two or more welded hooks), baitless hooks attached to the main line. The fish, when touched by the hook, may be caught, being hooked not only by the mouth, but by any other part of its body. When the fish escapes, it may be severely injured. Table 5 indicates that some fishers preferred the use of bait in association with the cevas.

\subsection{Description of the catches}

The captured species and their relative abundance, in number of individuals and in weight, are presented in Table 6. The largest relative catches (in number and in weight) were due to O. niloticus in all seasons, ex- 


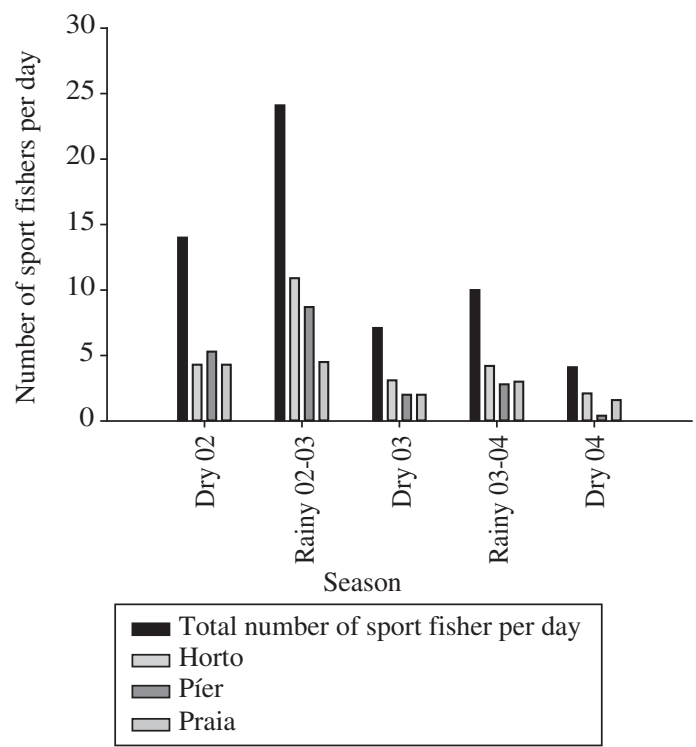

Figure 2. Distribution of number of sport fishers per visit, by fishing site and season, from 2002 to 2004.

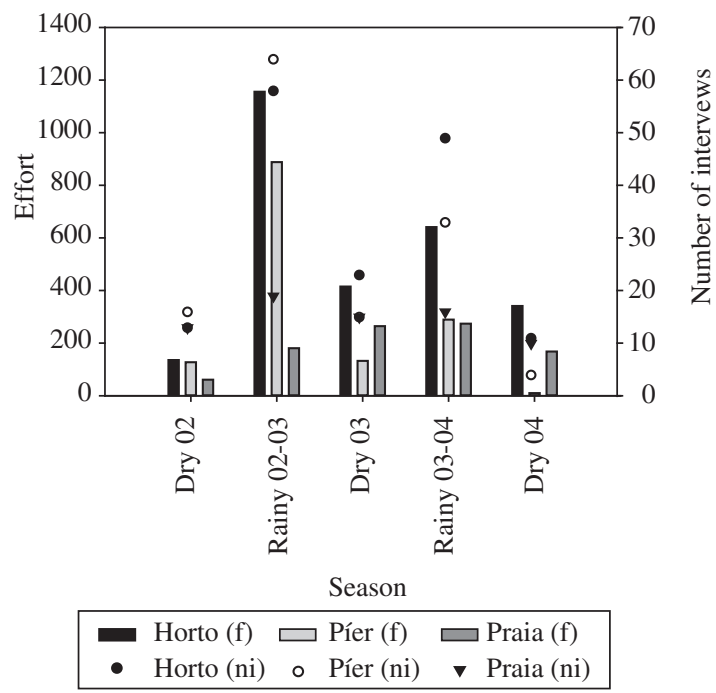

Figure 3. Distribution of fishing effort (f, in terms of number of fishing rods $\mathrm{x}$ fishing time) and number of interviews (ni) accomplished with the sport fishers by season.

Table 3. Relationship between fishing effort (number of rods $\mathrm{x}$ fishing time) divided by the number of accomplished interviews, for the dry and rainy seasons at three fishing sites (Horto, Píer and Praia).

\begin{tabular}{lcrc}
\hline \multicolumn{1}{c}{ Seasons } & Horto & Píer & Praia \\
\hline Dry season 2002 & 10.4 & 8.0 & 4.7 \\
Rainy season 2002-2003 & 19.9 & 13.9 & 9.5 \\
Dry season 2003 & 18.0 & 8.8 & 17.6 \\
Rainy season 2003-2004 & 13.1 & 8.8 & 17.1 \\
Dry season 2004 & 31.0 & 2.5 & 16.8 \\
\hline
\end{tabular}

Table 4. Comparison between the yield (kg/fisher) and fisher density (fisher $/ \mathrm{km}^{2}$ ) for the Lobo-Broa Reservoir.

\begin{tabular}{lcc}
\hline \multicolumn{1}{c}{ Season } & Yield (kg/fisher) & Fisher/km ${ }^{2}$ \\
\hline Dry 2002 & 0.11 & 6.2 \\
Rainy 2002/2003 & 0.22 & 74.6 \\
Dry 2003 & 0.10 & 25.1 \\
Rainy 2003/2004 & 0.10 & 36.8 \\
Dry 2004 & $<0.001$ & 8.4 \\
\hline
\end{tabular}

Table 5. Use of bait types by season and fishing site.

\begin{tabular}{llccc}
\hline Season & $\begin{array}{c}\text { Fishing } \\
\text { site }\end{array}$ & $\begin{array}{c}\text { Exclusive } \\
\text { use of } \\
\text { baits }(\%)\end{array}$ & $\begin{array}{c}\text { Use of } \\
\text { bait }+ \\
\text { ceva }(\%)\end{array}$ & $\begin{array}{c}\text { Exclusive } \\
\text { use of } \\
\text { bait }(\%)\end{array}$ \\
\hline \multirow{2}{*}{ Dry } & Horto & 17.7 & 72.6 & 9.7 \\
& Píer & 22.5 & 50.0 & 22.5 \\
& Praia & 21.4 & 61.9 & 16.7 \\
\multirow{4}{*}{ Rainy } & Horto & 30.4 & 65.2 & 4.3 \\
& Píer & 26.1 & 66.3 & 7.6 \\
& Praia & 19.4 & 51.6 & 29.0 \\
\hline
\end{tabular}

cept in the 2004 dry season, where just one individual of Pimelodella cf. gracilis weighing $200 \mathrm{~g}$ was caught. The catch and effort evaluation are shown in Figure 4. Higher catches and effort occurred in Horto. The largest values of catch per season occurred in the 2003-2004 rainy season (Figure 5).

The catch structure per season indicates that G. brasiliensis, O. niloticus and C. monoculus were caught in almost all seasons (Figure 6).

\subsection{Statistical analyses}

Figure 7 displays the linear and positive relationship between the natural logarithms of catch (lncw) and effort (lnf) with some scatter along the tendency line which is usual in this sort of observational data.

We test the full model (Equation 5). These analyses have a rather exploratory character when trying to understand the correlation structure among the variables and factors in the model, looking for a minimum model. So the interactions not significant at $5 \%$ level (we were quite restrictive here) were successively dropped. The final ANCOVA model (Equation 6) indicated the effect of the fishing site and (as usual) the fishing effort determining the catches:

$\ln \mathrm{cw}=\mu+\mathrm{FS}+\ln \mathrm{f}+\varepsilon$

The scatterplot between the studentized residuals $\mathrm{X}$ estimated values is presented in Figure 8, and the histogram of the residual, where the $\mathrm{g}_{1}$ and $\mathrm{g}_{2}$ tests are highly significant

$\left(\mathrm{g}_{1}=-0.7211 * *, \mathrm{~g}_{2}=2.0753 * *\right)$ is shown in Figure 9. Although the distribution of the residuals is not normal, 
Table 6. Percentage in number $(\mathrm{N})$ and weight (Wt-g) of the individuals caught by sport fishing during the study period.

\begin{tabular}{|c|c|c|c|c|c|c|c|c|c|c|}
\hline \multirow[t]{2}{*}{ Scientific name } & \multicolumn{2}{|c|}{$\begin{array}{c}\text { Dry season } \\
2002(\%) \\
\end{array}$} & \multicolumn{2}{|c|}{$\begin{array}{c}\text { Rainy season } \\
2003 / 2004(\%)\end{array}$} & \multicolumn{2}{|c|}{$\begin{array}{c}\text { Dry season } \\
2003(\%) \\
\end{array}$} & \multicolumn{2}{|c|}{$\begin{array}{l}\text { Rainy season } \\
2003 / 2004(\%)\end{array}$} & \multicolumn{2}{|c|}{$\begin{array}{c}\text { Dry season } \\
2004(\%)\end{array}$} \\
\hline & $\mathbf{N}$ & Wt & $\mathbf{N}$ & Wt & $\mathbf{N}$ & Wt & $\mathbf{N}$ & Wt & $\mathbf{N}$ & $\mathbf{W t}$ \\
\hline $\begin{array}{l}\text { Astyanax altiparanae } \\
\text { (Garutti and Britski) }\end{array}$ & 4.2 & 1.20 & 1.8 & 0.20 & - & - & 8.0 & 0.4 & - & - \\
\hline $\begin{array}{l}\text { Hoplias malabaricus } \\
\text { (Bloch) }\end{array}$ & - & - & 0.4 & 0.30 & - & - & - & - & - & - \\
\hline $\begin{array}{l}\text { Hoplerithrynus unitaeniatus } \\
\text { (Spix and Agassiz) }\end{array}$ & - & - & 0.5 & 0.30 & - & - & - & - & - & - \\
\hline Leporinus fridericii (Bloch) & - & - & 0.4 & 0.60 & - & - & - & - & - & - \\
\hline $\begin{array}{l}\text { Pimelodella cf. gracilis } \\
\text { (Valenciennes) }\end{array}$ & - & - & - & - & - & - & - & - & 100.0 & 100.00 \\
\hline $\begin{array}{l}\text { Cyphocharax modesta } \\
\text { (Fernández-Yépez) }\end{array}$ & - & - & 0.2 & 0.10 & - & - & 3.0 & 0.7 & - & - \\
\hline Tilapia rendalli (Boulenger) & - & - & 1.9 & 0.80 & 2.8 & 2.5 & 22.0 & 10.6 & - & - \\
\hline $\begin{array}{l}\text { Oreochromis niloticus } \\
\text { (Linnaeus) }\end{array}$ & 54.2 & 47.40 & 77.5 & 86.7 & 80.6 & 85.8 & 57.0 & 80.6 & - & - \\
\hline $\begin{array}{l}\text { Geophagus brasiliensis } \\
\text { (Quoy and Gaimard) }\end{array}$ & 33.3 & 40.90 & 16.7 & 9.60 & 11.1 & 3.2 & 8.0 & 5.5 & - & - \\
\hline $\begin{array}{l}\text { Cichla monoculus } \\
\text { (Spix and Agassiz) }\end{array}$ & 8.3 & 10.50 & 0.7 & 1.30 & 5.6 & 8.5 & 2.0 & 2.2 & - & - \\
\hline Total (N/Wt-g) & 48.0 & 4.52 & 569.0 & 111.69 & 36.0 & 16.7 & 100.0 & 25.0 & 1.0 & 0.02 \\
\hline
\end{tabular}

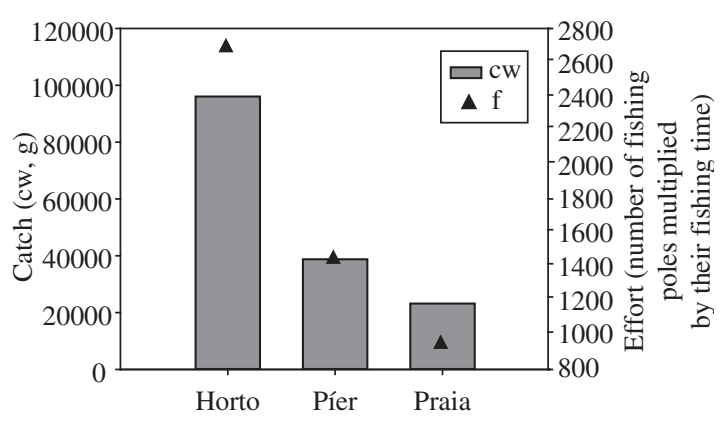

Figure 4. Catch (cw, g) and effort (f, number of fishing rods multiplied by their fishing time) at the fishing sites (Horto, Píer and Praia) in the Lobo Broa Reservoir.

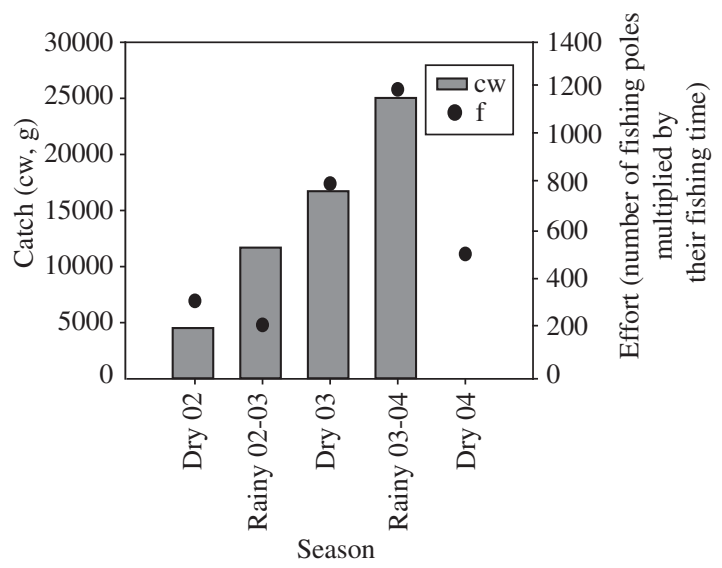

Figure 5. Catch (cw, g) and effort (f, number of fishing rods multiplied by their fishing time), for the dry and rainy stations during the study period at Lobo Broa Reservoir.



Figure 6. Distribution of the catches (\% weight) per season per species.

we still stick with Equation 6, because the design is balanced, rendering robust $F$ tests (Huitema, 1980).

Only one significant difference between the adjusted means was detected between Horto and Píer (Table 7).

\section{Discussion}

Petrere et al. (2002) affirmed that in smaller reservoirs like Ibitinga and Bariri (Tietê River) and Salto Grande (Paranapanema River), small-scale fishing is practiced more than sport fishing. In larger dams, like 
Table 7. Multiple comparison tests a posteriori between the adjusted means of lncw (natural logarithm of the catches, g) by the ANCOVA final model in the three fishing sites. The numbers between brackets indicate the antilogarithms of the adjusted means.

\begin{tabular}{lccc}
\hline $\begin{array}{c}\text { Fishing } \\
\text { sites }\end{array}$ & $\begin{array}{c}\text { Adjusted mean } \\
\text { catches }(\mathbf{g}) \pm \text { se }\end{array}$ & Comparisons & $\boldsymbol{t}$-test \\
\hline $\begin{array}{l}\text { Horto } \\
(1)\end{array}$ & $\begin{array}{c}6.9928 \\
(1088.77) \pm 0.1708\end{array}$ & 1 e 2 & $4.1672^{*}$ \\
Píer & 6.0700 & 2 e 3 & $1.3633 \mathrm{~ns}$ \\
$(2)$ & $(432.68) \pm 0.1816$ & & \\
Praia & 6.4832 & 1 e 3 & $1.6846 \mathrm{~ns}$ \\
$(3)$ & $(654.06) \pm 0.3650$ & & \\
\hline
\end{tabular}

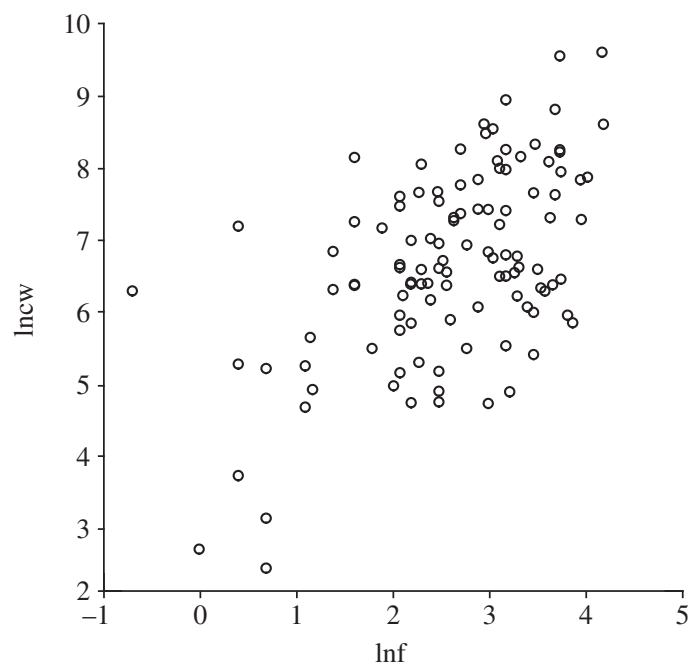

Figure 7. Relationship between lncw (natural logarithms of catch, g) and lnf (natural logarithm of the fishing effort, number of fishing rods multiplied by their fishing time) for sport fishing in Lobo Broa Reservoir.

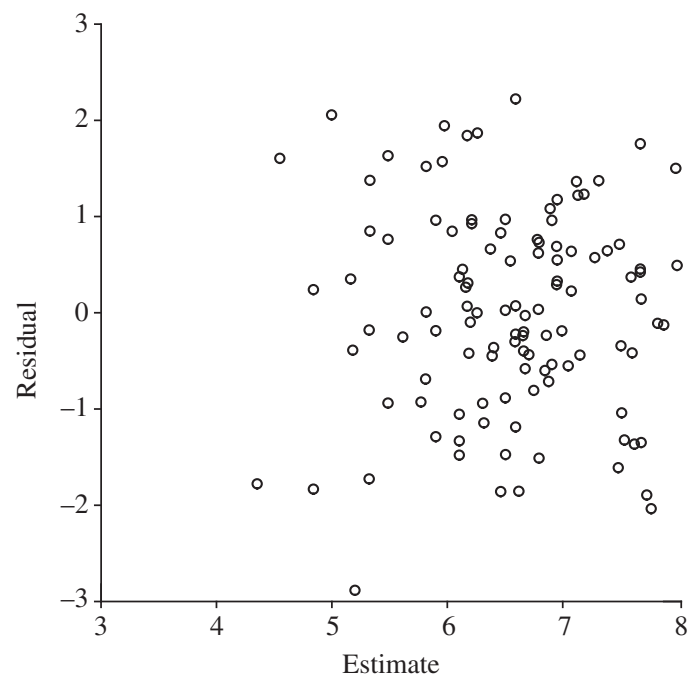

Figure 8. Studentized residuals versus the lncw estimated values.

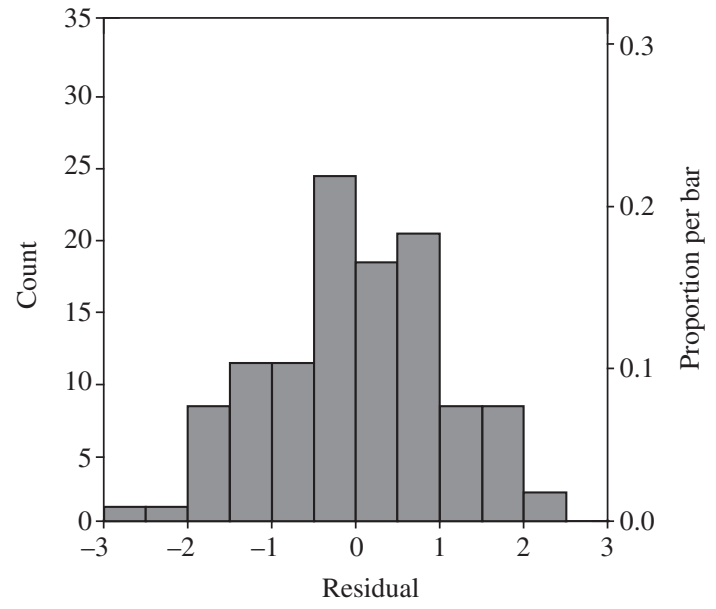

Figure 9. Histogram of the residuals of the final ANCOVA $\operatorname{model}\left(\mathrm{g}_{1}=-0,7211 * * ; \mathrm{g}_{2}=2,0753 * *\right)$.

Jupiá, Itaipu (Paraná River), Barra Bonita, Promissão (Tietê River), professional fishing prevails, in spite of the presence of sport fishers just at weekends. In the LoboBroa reservoir, only one professional fisher was interviewed.

According to Argenton (2004), the Horto area of Lobo-Broa reservoir is classified as meso-oligotrophic with higher nutrient concentrations and conductivity and the smallest oxygen concentrations were caused by the effluents brought by Itaqueri River and high turbidity due to sand mining. Such conditions can favour fish catches (Walter, 2000). Arcifa et al. (1988) associated increased turbidity to higher catches in the reservoir of Americana (SP). The eutrophication process can still contribute to the establishment of species such as the tilapia, which does not demand clean water (Ribeiro-Filho, 2002).

In Horto, the presence of wood stakes in the water for the fixing of chairs or benches, would also improve catches. Such stakes could act as artificial reefs supplying substratum for periphyton and benthos, refuge for fish and lessening marginal erosion (Agostinho et al., 2000).

The Praia area has high fish yield, statistically similar to the Horto area, due to higher fishing effort and the particular water circulation pattern and the higher temperatures, enhancing secondary productivity (A. Saggio, 2004, personal communication to JMAP).

Fish production $(\mathrm{kg} / \mathrm{ha} / \mathrm{year})$ is low when compared to the data of Petrere et al. (2002), as seen in Table 8 . The low catches in Lobo-Broa reservoir can be associated to the presence of more than two predators (Hoplias malabaricus and C. monoculus, macro carnivorous; Hoplerithrynus unitaeniatus a small sized facultative predator; Rhamdia quelen small sized predator; Astyanax altiparanae, A. scabripinnis paranae micro carnivores), due to the increased competition for resources (Paiva et al., 1994). Fernando et al. (1998) considered 
Table 8. Comparison among the fish production $(\mathrm{kg} / \mathrm{ha} /$ year) and flooded area for seven reservoirs of the Paraná River basin (Petrere et al., 2002) and this study.

\begin{tabular}{lcc}
\hline \multicolumn{1}{c}{ Reservoir } & $\begin{array}{c}\text { Flooded } \\
\text { area (ha) }\end{array}$ & $\begin{array}{c}\text { Production } \\
\text { (kg/ha/year) }\end{array}$ \\
\hline $\begin{array}{l}\text { Jupiá (Grande River) } \\
\begin{array}{l}\text { Água Vermelha } \\
\text { (Grande River) }\end{array}\end{array}$ & 35,200 & 4.7 \\
$\begin{array}{l}\text { Barra Bonita } \\
\text { (Tietê River) }\end{array}$ & 33,4300 & 2.9 \\
$\begin{array}{l}\text { Ibitinga (Tietê River) } \\
\text { Promissão (Tietê River) }\end{array}$ & 11,400 & 6.0 \\
$\begin{array}{l}\text { Nova Avanhandava } \\
\text { (Rio Tietê) }\end{array}$ & 21,700 & 3.2 \\
$\begin{array}{l}\text { Itaipu (Paraná River) } \\
\text { Lobo Broa Reservoir }\end{array}$ & 135,000 & 13.3 \\
(this study) & 680 & $<1.0$ \\
\hline
\end{tabular}

that reservoirs mainly fished for recreation present lower catches than the ones mostly exploited by commercial fishing. They also mentioned that the introduction of tilapia in the tropics and of sardines in Lake Tanganika is responsible for higher catches.

The high $O$. niloticus catches, predominant in almost all of the fishing sites in Lobo-Broa reservoir can be attributed to species of omnivorous habits, when exploiting coastal habitats becomes more vulnerable to be caught by the sport fishers, who usually fish at the reservoir margin (Ribeiro-Filho, 2002). Fernando and Holcík (1985) and Paiva et al. (1994) reported that the introduction of $O$. niloticus in the reservoirs of NE Brazil has become dominant in commercial catches. The success of the introduction of tilapias in the Billings reservoir (SP), is due to some biological characteristics of this fish such as its high reproductive potential, capacity to ingest plankton, resistance to low concentrations of dissolved oxygen, and to its tolerance of chemical contaminations (Minte-Vera and Petrere, 2000).

The catches in weight in sports fishing were shown to be dependent on the fishing site and fishing effort as described by the ANCOVA model. Cetra (1998) and Petrere (1986) observed that increase in effort significantly increases catches in professional fishing in the middle river Tocantins (MA) and in the Amazon, respectively.

Seasonality was not shown to be significant in the final model. In other words, the temperature and pluviosity effects in the reservoir area did not affect fish catches. The small difference between mean temperature for the summer and for the winter and the low pluviosity in this last period, contrasting with abundant rains in the summer during the study period, behaved like the data described by Argenton (2004), Marinelli (2002), Queirós (2000) and Tundisi (1986). The rainy period seems not to affect the captures because during the rains, the flood- gates were open to release the excess of water, so reducing fluctuation level. On the other hand, the study of Wudneh (1998) in Lake Tana, Ethiopia, showed that seasonality is an important factor in the capture of Barbus tsanensis and for the largest Oreochromis niloticus and B. platydorsus, in trawl fishing.

Anyway seasonality seems to be a more strong influence in floodplain rivers than in lakes and reservoirs. It is now well accepted, and as Cetra (1998) mentioned, in floodplain rivers, the periodic variation in river level is essential to the maintenance of fish diversity and biomass. The largest catches in his study occurred between May and August not only due to decrease in the river level, but also to the fish migration period, with the consequent fishing effort increasing upon shoals and the use of trawling. Seasonality also had an effect on the cpue values for the captures of Clarias gariepinus and on the other three fish species studied (Cetra op.cit.). Ribeiro and Petrere (1990) point out that water level fluctuation of the Negro River, associated with different fishing habitats, are important factors determining catches. In the Itaipu reservoir Okada et al. (1996) observed the largest catches in spring - summer. The dry season is not well marked in South Brazil and according to Julio-Jr. et al. (1997), the landings in Itaipu reservoir were more related to the kind of gear employed associated to more intense fish activity in the summer due to higher temperatures.

In this study, the fishing sites were shown to be statistically significant in determining catches. So the mean catches between Horto and Píer were statistically different, but the comparisons between Horto and Praia and between the Praia and Píer were not. This may be explained by the proximity of Horto to the mouth of Itaqueri River which carries untreated sewage (Argenton, 2004). In Praia, the second mean catch was registered due to the absence of vegetal covering, which would contribute with nutrients. The similarity between the catches in Praia and Píer can be justified due to the proximity of the two sites.

The type of bait used was shown to be not significant. In other words, unlike many fishers believed, the association between bait and ceva, or just the use ceva, does not increase the captures. So our advice is that the discontinuity of this practice could improve the water quality of the reservoir in Horto, principally because the water presented high phosphorus concentrations, which is above the recommended level by Brazilian legislation (resolution 20/86 of CONAMA, Conselho Nacional do Meio Ambiente) (Argenton, 2004). Despite the fishing of carp being selective due to bait size, Arlinghaus and Mehner (2003) in Germany credited the increase of water eutrophication to the discarded bait, when no fish is hooked.

Templeton (1984) considered rod fishing appropriate for large or small lakes, to rivers and others water bodies. The captures depend on the spatial the fishing effort and the techniques used. Arlinghaus et al. (2003) believed in the sociocultural and socioeconomic benefits generated 
by sport fishing in Europe, in spite of the negative impacts in the aquatic ecosystems.

Agostinho and Gomes (2005) mentioned that in Brazil, fishing management can be addressed for the preservation of biological diversity and/or to sustain stock density in two ways: 1) management with a conservationist purpose: to be adopted in order to maintain the population density above critical demographic and genetic thresholds important for reproduction and evolutionary processes, and 2) exploitation management: to maintain a maximum income from the fishing activity, adopting measures that increase recruitment, improving the environment biogenic capacity, so reducing natural mortality and then monitoring fishing.

Little has been done in relation to the management of the stocks of Lobo-Broa reservoir involving the fishers. The more productive Horto area does not have any sheltering facilities for the fishers. Some haphazard fish introductions are accomplished by fishers, without any previous studies. In Broa reservoir and in Ilha Grande Park (Zacarkim et al., 2005) the interviewed sport fishers agreed that professional fishing (cast nets and gillnets) should be prohibited in order to keep the fishing resource just for themselves. However, in this study, there were several sport fishers who fished with nets, but didn't trade the fishes, and are not considered professional fishers.

Investments in sport fishing tourism would promote local development in a sustainable way. Appropriate stock management and maintenance of water quality in Lobo-Broa reservoir could guarantee that the native stock was not overexploited, as well as controlling the alien species stocks.

Acknowledgements - This paper is part of an MSc dissertation submitted by JMAP at CHREA/USP supervised by MPJr. The authors thank FAPESP (Processo no. 02/12576-0) for the financial support to JMAP, and CHREA-USP for the facilities. UNESP and CNPq partially financed MPJr.

\section{References}

ABE, DS., ARANTES, JD., MINOTI, RT., PETRACCO, P., SILVA, WM. and TUNDISI, JG., 2000. O processo de eutrofização na Represa do Lobo (Itirapina, SP): Condições atuais e perspectivas futuras. In Seminário Internacional: Represa do Lobo-Broa 30 anos. São Carlos: IIE/ CRHEAUSP/ PPG-ERN-DEBE-UFSCar/ IEA-USP. 26 p. (Resumos).

AGOSTINHO, AA. and GOMES, LC., 2005. O manejo da pesca em reservatórios da Bacia do Alto Rio Paraná: avaliação e perspectivas. In Nogueira, MG., Henry, R., and Jorcin, A. (Eds.). Ecologia de reservatórios. São Carlos, SP: Ed. Rima. p. 23-55.

AGOSTINHO, AA., GOMES, LC. and OKADA, EK., 2000. Remoção de paliteiro em reservatórios e efeitos sobre a pesca. Bol. Soc. Bras. Limn., no. 28, p. 12-13.

ALBINO, ALD., 1987. Estudo sobre a fauna de peixes da bacia do rio Jacaré- Guaçu (Estado de São Paulo) com uma avaliação preliminar dos efeitos de dois barramentos. São Carlos: UFSCar. 168 p. [MSc. Dissertation].
ANGELINI, R., 1995. Análise do ecossistema da represa do Broa (S) através de um Modelo Estatístico (ECOPATH II) e um modelo de simulação (STELLA II). São Carlos: CRHEA/ EESC/ USP. 121 p. [MSc. Dissertation].

ARCIFA, MS., FROEHLICH, O. and NORTHCOTE, TG., 1988. Distribution and feeding ecology of fishes in a tropical Brazilian reservoir. Soc. Ciênc. Naturales La Salle. Tomo XLVIII, p. 301-325.

ARGENTON, EC., 2004. Limnologia, balneabilidade $e$ impactos ambientais: uma análise temporal e espacial na represa do Lobo (Broa), Itirapina/ Brotas- SP. São Carlos: CRHEA/ EESC/ USP. 146 p. [MSc. Dissertation].

ARLINGHAUS, R. and MEHNER, T., 2003. Socio-economic characterization of specialized common carp (Cyprinus carpio) anglers in Germany, and implications for inland fisheries management and eutrophication control. Fish. Res., vol. 61, no. 1-3, p. 19-33.

ARLINGHAUS, R., MEHNER, T. and COWX, IG., 2002. Reconciling traditional inland fisheries management and sustainability in industrialized countries, with emphasis on Europe. Fish and Fisheries, vol. 3, no. 4, p. 261-316.

BELL, FW., 1997. The economic valuation of saltwater marsh supporting marine recreational fishing in the southeastern United States. Ecological Economics. vol. 21, no. 3, p. 243-254.

BENI, MC., 1998. Análise estrutural do turismo. São Paulo: Senac. 515 p.

BARBIERI, G., 1974. Crescimento de Geophagus brasiliensis (Quoy \& Gaimard, 1824) na represa do Lobo. São Paulo, 111 p. [MSc. Dissertation].

BARBIERI, G., 1975. Sobre o crescimento relativo do Geophagus brasiliensis (Quoy \& Gaimard, 1824) na represa do Lobo, Estado de São Paulo. São Paulo: USP, 135 p. [PhD Thesis].

BARBIERI, MC. and GARAVELO, JC., 1981. Sobre a dinâmica da reprodução e da nutrição de Leporinus friderici (Bloch, 1794) na represa do Lobo, Brotas- Itirapina (SP) (Pisces, Anastomidae). An. Sem. Reg. Ecol. III. (UFSCar, São Carlos), p. 347-387.

BARBIERI, G. and BARBIERI, MC., 1984. Crescimento de Gymnotus carapo (Linnaeus, 1758) na represa do Lobo, estado de São Paulo, pelo método da distribuição da frequiência de comprimento (Pisces, Gymnotidae). Rev. Bras. Biol., vol. 44, no. 3, p. 239-246.

BARBIERI, MC. and BARBIERI, G., 1984. Reprodução de Gymnotus carapo (Linnaeus, 1758) na represa do Lobo (SP). Morfologia e histologia de testículo. Variação sazonal. (Pisces, Gymnotidae). Rev. Brasil. Biol., vol. 44, no. 2, p. 141-148.

BARBIERI, G., 1988. Curva de maturação, tamanho de primeira maturação gonadal e fecundidade de Astyanax bimaculatus e Astyanax fasciatus da represa do Lobo, Estado de São Paulo (Osteichthyes, Characidade). Rev. Ceres, vol. 35, no. 197, p. 64-77.

BARBIERI, G. and SANTOS, EP., 1988. Análise comparativa do crescimento e de aspectos reprodutivos da piava Leporinus friderici (Bloch, 1794) (Osteichthyes, Anostomidae) da represa do Lobo e do rio Mogi-Guaçu, Estado de São Paulo. Cien. Cult., vol. 40, no. 7, p. 693-697. 
BARBIERI, G., BARBIERI, MC., 1991. Biologia reprodutiva de fêmeas de Leporinus octofasciatus (Steindachner, 1917) (Characiformes, Anastomidas) da represa do Lobo, São Paulo. Notas preliminares, São Carlos, SP. An. Sem. Reg. Ecol., vol. 6, p. 293-301.

CALIJURI, MC., 1985. Curvas de luz-fotossíntese e fatores ecológicos em ecossistema artificial e não estratificado-Represa do Broa (Horto/Itaqueri)- São Carlos- SP. São Carlos: UFSCar, 280 p. [MSc. Dissertation].

CALIJURI, MC., TUNDISI, JG., 1990. Limnologia comparada das represas do Lobo (Broa) e Barra Bonita- Estado de São Paulo: mecanismos de funcionamento e bases para o gerenciamento. Rev. Bras. Biol., vol. 50, no. 4, p. 893-913.

CATELLA, AC., 2005. Reflexões sobre a pesca esportiva no Pantanal Sul: crise e perspectivas. [September 7, 2005]. Available from: http://www.ibama.gov.br/pndpa/.

CETRA, M., 1998. Ecologia da pesca no médio rio Tocantins, Imperatriz (MA). São Carlos: CRHEA/EESC/USP. 72 p. [MSc. Dissertation].

DORNFELD, CB., MASUTTI, MB., SILVÉRIO, PF., ANDRADE, CA., and ALMEIDA, C., 2002. Caracterização eco toxicológica do sedimento da represa do Lobo e seus tributários. In Programa de Pós Graduação em Ciências da Engenharia Ambiental- CRHEA/ EESC/ USP. Recursos Hidroenergéticos: Usos, impactos e planejamento integrado. São Carlos: Ed. Rima, p. 75-89.

FERNANDO, CH. and HOLČÍK, J., 1982. The nature of fish communities: A factor influencing the fishery potential and yields of tropical lake and reservoirs. Hydrobiologia, vol. 97, no. 2 , p. 127-140.

FERNANDO, CH., GURGEL, JJS. and MOYO, NAG., 1998. A global view of reservoir fisheries. Internat. Rev. of Gesamten. Hydrobiol., vol. 83, p. 31-42.

FRAGOSO, EN., SOUZA, JE., VELLUDO, MR., SOARES, AS., SILVA, LH., RODRIGUES-FILHO, JL., FENERICHVERANI, N., VERANI, JR. and ROCHA, O., 2005. Introdução de espécies e estado atual da ictiofauna da represa do Lobo, Broa - Itirapina, SP. In ROCHA, O., ESPÍDOLA, ELG., FRENERICH-VERANI, N., VERANI, JR., RIETZLER, AC. (Eds.). Espécies invasoras em águas doces: estudos de caso e propostas de manejo. São Carlos: Editora Universidade federal de São Carlos. p. 45-46.

FREIRE, O., GIMENES, RJ., PESSOTTI, JE., and CARRARO, E., 1980. Solos da bacia do Broa. São Carlos: UFSCar. $85 \mathrm{p}$.

GIAMPIETRO, RL., OHNUMA Jr., AA., BENINI, RM., and ESPÍNDOLA, ELG., 2004. Caracterização e diagnóstico preliminar das áreas de preservação permanente do Ribeirão Itaqueri, Itirapina, SP. In ESPÍNDOLA, ELG. and WENDLAND, E. (Ed.). Bacia Hidrográfica: Diversas abordagens em pesquisa. São Carlos, SP: Ed. Rima. p. 73-90.

HUITEMA, BE., 1980. The analysis of covariance and alternatives. New York: John Wiley \& Sons. 445 p.

JØRGENSEN, SE. and VOLLENWEIDER, RA., 2000. Princípios para o Gerenciamento de Lagos. São Carlos: ILEC, IIE. 84 p.

JULIO JR., HF., BONECKER, CC. and AGOSTINHO, AA., 1997. Reservatório de Segredo e sua inserção na bacia do rio Iguaçu. In Agostinho, AA., and Gomes, LC. (Eds.).
Reservatório de Segredo: bases ecológicas para o manejo. Maringá: EDUEM. p. 1-18.

KERKVLIET, J. and NOWELL, C., 2000. Tools for recreation management in parks: the case of the grater Yellowstone's blueribbon fishery. Ecological Economics, vol. 34, no. 1, p. 89-100.

KENDALL, RL., 1991. Preface and acknowledgements: Proceedings of the International Symposium and Workshop on Creel and Angler Surveys in Fisheries Management. Am. Fish. Soc. Symp., vol. 12, p. xi-xii.

KING, M., 1995. Fisheries biology, assessment andmanagement. Oxford: Fishing New Books. 341p.

LORANDI, R., FREIRE, O., FRANÇA, GV. and TAKAOKA, M., 1983. Interpretação do levantamento de solos da bacia da represa do Lobo para fins de estudos ecológicos. In Anais do III Seminário Regional de Ecologia. São Carlos: UFSCar. p. 331-341

LUCENA, FM., 2000. Species interaction in fish stock assessment and management in Southern Brazil: a bio-economic approach. Norwich, England: University of East Anglia. 235 p. [PhD Thesis]

MARINELLI, CE., 2002. Estrutura da comunidade, habitats e padrões de distribuição da ictiofauna em ecótonos do reservatório do Broa, SP. São Carlos: CRHEA/ EESC/ USP. 225 p. [MSc. Dissertation].

MINTE-VERA, CV. and PETRERE, M., 2000. Artisanal fisheries in urban reservoirs: a case study from Brazil (Billings Reservoir, São Paulo, Metropolitan Region). Fish. Man. Ecol., vol. 7, no. 6, p. 537-549.

MIRANDA, LE., 1999. Recreational catfish harvest in reservoirs in the USA. Fish. Man. Ecol., vol. 6, no. 6, p. 499-513.

MORAES, EM., 1978. Ciclo sazonal, distribuições horizontal e vertical e inter-relação ecológicas de nutrientes na Represa do Lobo (Brotas- Itirapina- SP). São Paulo: IB/USP, 153 p. [MSc. Dissertation].

MURRAY-JONES, S. and STEFFE, AS., 2000. A comparison between commercial and recreational fisheries of surf clam, Donax deltoids. Fish. Research, vol. 44, no. 3, p. 219-233.

NISHIYAMA, L., 1991. Mapeamento geotécnico preliminar da quadrícula de São Carlos, SP. São Carlos: Geotecnia, EESC/ USP. 228 p. [MSc. Dissertation].

O'CONNEL, MF., 2003. An examination of the use of angling data to estimate total returns of Atlantic salmon, Salmo salar, to two rivers in Newfoundland, Canada. Fish. Man. Ecol., vol. 10, no. 4, p. 201-208.

OKADA, EK., AGOSTINHO, AA. and PETRERE, M., 1996. Catch and effort data and the management of the commercial fisheries of Itaipu reservoir in the upper Paraná River, Brazil. In Cowx, IG. (Ed.). Stock assessment in inland fisheries. Fishing News Books, p. 154-161.

PAIVA, MP.,PETRERE, M.,PETENATE,AJ.,NEPOMUCENO, FH. and VASCONCELOS, EA., 1994. Relationship between the number of predatory fish species and fish yield in large northeastern Brazilian reservoirs. In Cowx, IG. (Ed.). Rehabilitation of freshwater fisheries. $1^{\text {st }}$ ed. Bodman, UK: Fishing News Books, v. 1, p. 120-129.

PEREIRA, JMA., 2005. A atividade pesqueira na represa do Lobo-Broa (Itirapina, Brotas - SP): caracterização $e$ 
composição da captura. São Carlos: CRHEA/ EESC/ USP. 130 p. [MSc. Dissertation].

PET, JS., WIJSMAN, JWM., MOUS, PJ. and MACHIELS, MAM., 1995. Characteristics of a Sri Lanka reservoir fishery and consequences for the estimation of annual yield. In PET, JS. (Ed.). On the management of tropical reservoir fishery. The Netherlands: Wageningen University. 161 p. [Thesis]

PETRERE, M., 1978. Pesca e esforço no Estado do Amazonas. I. Esforço e captura por unidade de esforço. Acta Amazonica, vol. 8 , no. 3, p. 439-454.

PETRERE, M., 1986. Amazon fisheries. II-Variations in the relative abundance of tucunaré (Cichla ocellaris, $C$. temensis) based on catch and effort data of the trident fisheries. Amazoniana, vol.10, no. 1, p. 1-13.

PETRERE, M., AGOSTINHO, AA., OKADA, EK. and JÚLIO Jr., HF., 2002. Review of the fisheries in the Brazilian portion of the Paraná/Pantanal basin. In COWX, IG. (Ed.). Management and Ecology of Lake and Reservoir Fisheries. Bodman, UK: Fishing New Books. p. 123-143.

RIBEIRO-FILHO, RA., 2002. Estudo experimental de biomanipulação: análise dos impactos ambientais de duas espécies de predadores no controle de tilápia no Lago Paranoá (Brasília, DF). São Carlos: CRHEA/ EESC/ USP. 91 p. [MSc. Dissertation].

RIBEIRO, MCLB. and PETRERE, M., 1990. Fisheries ecology and management of the jaraqui (Semaprochilodus taeniurus, S. insignis) in central Amazonia. Reg. Rivers: Research \& Management, vol. 5, no. 3, p. 195-215.

ROCHA, O., 1978. Flutuação sazonal e distribuição da população Diaptomus furcatus, Sars (Copepoda, Calanóida) na represa do Lobo (Broa). São Carlos: USP. 147 p.

SIPPONEN, MS., 2001. The development of the Finnish inland fisheries system. Fish. Man. Ecol., vol. 8, no. 4-5, p. 383-391.

SIPPONEN, MS. and MUOTKA, M., 1996. Factors affecting the demand for recreational fishing opportunities in Finnish lakes during the 1980 's. Fisheries Research, vol. 26, no. 3-4, p. $309-323$

SOUZA, MHAO., 1977. Alguns aspectos ecológicos da vegetação na região perimetral da represa do Lobo (BrotasItirapina, SP). São Paulo: IB/USP. 369 p. [MSc. Dissertation].

SOUZA, JE., VELLUDO, MR., FRAGOSO, EN., SABINSON, LM., FENERICH-VERANI, N., VERANI, JR., ROCHA, O., 2005. Estrutura da população e aspectos reprodutivos de Cichla cf. ocellaris BLOCH \& SCHNEIDER, 1801 (Perciformes, Cichlidade) introduzido na represa do Lobo (Broa), estado de São Paulo. In ROCHA, O., ESPÍDOLA, ELG., FENERICHVERANI, N., VERANI, JR., RIETZLER, AC. (Eds.). Espécies invasoras em águas doces: estudos de caso e propostas de manejo. São Carlos: Editora Universidade Federal de São Carlos. p. 59-72.
STRAŠKRABA, M. and TUNDISI, JG., 2000. Diretrizes para o gerenciamento da qualidade da água de represas. São Carlos: IIE- Instituto Internacional de Ecologia. 258 p.

STRIXINO, GMA., 1973. Sobre a ecologia dos macroinvertebrados do fundo, na represa do Lobo. São Paulo: IB/ USP. 188 p. [PhD. Thesis].

SYSTAT, 2000. Version 10. Standard Version. SPSS Inc.

TEMPLETON, RG., 1984. Freshwater fisheries management. England: Fishing New Books.

TUNDISI, JG., 1977. Produção primária, standing-stock, fracionamento do fitoplâncton e fatores ecológicos em ecossistema lacustre artificial (Represa do Broa, São Carlos). Ribeirão Preto: IB/ USP. 490 p. [Tese].

-, 1986. Local community involvement in environmental planning and management: focus on river basin management The Horto/ Itaqueri-Broa reservoir case study. Expert group on Environmental Planning and Management for Local Regional Development: focus on training aspects derived from studies of inland water management. Otsu e Nagoya, Japan, November 10-21, p. 36.

TUNDISI, JG., MATSUMURA-TUNDISI, T., 1995. The Horto/ Itaqueri-Broa ecosystem research. In: Tundisi, JG., Bicudo, CEM., Matsumura- Tundisi, T. (Eds.). Limnology in Brazil. Rio de Janeiro: Brazilian Academy of Sciences and Brazilian Limnological Society, p. 219-243.

TUNDISI, JG., MATSUMURA-TUNDISI, T. and RODRIGUES, SL., 2003. Gerenciamento e recuperação das bacias hidrográficas dos rios Itaqueri e do Lobo e da UHE Carlos Botelho (Lobo-Broa). São Carlos: IIE, IIEGA. 54 p.

VELLUDO, MR., FRAGOSO, EN., SOUZA, JE., LOEB, MV., FENERICH-VERANI, N., VERANI, JR., and ROCHA, O., 2005. Dinâmica alimentar de Cichla cf. ocellaris BLOCH \& SCHNEIDER, 1801 (Perciformes, Cichlidade) introduzido na represa do Lobo (Broa), Brotas, Itirapina, SP. In ROCHA, O., ESPÍDOLA, ELG., FENERICH-VERANI, N., VERANI, JR., RIETZLER, AC. (Eds.). Espécies invasoras em águas doces: estudos de caso e propostas de manejo. São Carlos: Editora Universidade Federal de São Carlos. p. 73-86.

WALTER, T., 2000. Ecologia da pesca artesanal no Lago Paranoá, Brasília-DF. São Carlos: CRHEA/ EESC/ USP. 227 p. [MSc. Dissertation].

WHITAKER, VA., 1987. Ciclo sazonal das espécies químicas de ferro no reservatório do Horto/ Itaqueri (Broa). São Carlos: CRHEA/ EESC/ USP. 152 p. [MSc. Dissertation].

WUDNEH, T., 1988. Temporal and spatial dynamics in the sizerelated distribution patterns of Clarias gariepinus, Oreochromis niloticus, Barbus tsanensis and Barbus platydorsus. In Wudneh, T. (Ed.). Biology and management of fish stocks in Bahir Dar Gulf, Lake Tana, Ethiopia. Wageningen, NL. p. 43-52.

ZACARKIM, CE., FERRARI, E. and FREITAG, M., 2005. Perfil do pescador amador participante de eventos de pesca na região do Parque Nacional de Ilha Grande. [September 7, 2005]. Available from: http://www.ibama.gov.br/pndpa/. 